\title{
The Role of High School in Managing Conflicts that Generate Violence between Albanian Teenagers in Rural Areas
}

\author{
Eljana Brahja, PhD Candi \\ Faculty of Social Sciencies, Tirana University
}

\begin{abstract}
The purpose of this study is to determine the role of high school in managing conflicts between teenagers in the rural areas between Tirana and Elbasan. Conflicts among teenagers are always present. They can happen in families, at school, and in the community, but our focus will be the conflicts generated in school premises. It is concerning that teenagers are seeing school as a battlefield where they can fight away from their parents' eyes. The research will shed light on how the aid offered by the high school social services, impact teenagers' conflict management. This study uses Psychoanalytic, Humanist and Behavioral Directions to explain the source of violent behavior among students in schools located in rural areas. The study is based on the Positive Paradigm. The research method used for collecting data is the quantitative one. The population of this study is the teenagers of high schools located in rural areas between Tirana and Elbasan. The sample of the study is the students of "Krrabë" and "Ibrahim Hasmema" high schools and the instrument used is the sociological questionnaire. Data analysis will show whether teenage conflicts exist and how schools located in rural area manage these conflict cases. The document argues that conflicts between teenagers are present at school premises and the latest rarely use the social services provided at their school. The teachers' staff should be trained on identifying young people who tend to conflict and to have violent behavior. Teachers should be also trained on the ways to treat those teenagers who are victims of violence.
\end{abstract}

Keywords: teenagers' conflicts, physical violence, school role, conflict management, psycho-social service.

\section{Introduction}

All of us, in certain situations, may show violent behaviors. In some cases it can be practiced in direct forms, and sometimes it may be hidden. According to the World Health Organization, violence is defined as: "the intentional use of physical force or power, threatened or actual, against oneself, another person, or against a group or community that either results in or has a high likelihood of resulting in injury, death, psychological harm, maldevelopment, or deprivation" (Save the Children, 2007, p. 17). But only its definition is not enough. Violence has already turned into a social problem. It affects people of different ages, and the consequences that it causes in some cases are unrecoverable. One of the most visible types of violence is the one exerted by teenagers. The place where it happens most often is the high school (Council of Europe Study, 2017). Nowadays, schools are seen as an arena of violent events involving students and teachers. Even though a "traditional phenomenon", it should be identified and isolated (Jorgaqi, 2001, p.7-8).

At school premises, the teenagers seem to feel free to display forms of violence. Sometimes in the bully position, sometimes in the role of the victim, they are constantly being affected by this phenomenon. From a study conducted in Albania in 2017, it resulted that in $11^{\text {th }}$ grade students, the number of aggressors and victims was almost the same: $11.2 \%$ were declared as aggressors and $12.1 \%$ as victims (Council of Europe \& ISOP, 2017, p.19) ${ }^{1}$. The National Study on Bullying and Extremism in the Albanian Education System, referring to the designated sample, concluded that $20 \%$ of Albanian students from IV to XII grade in public and private schools, claimed to be involved in the phenomenon of Bullying in school (Council of Europe Study, 2017)2.

\footnotetext{
${ }^{1}$ The Council of Europe Office in Tirana. $21 \mathrm{Apr}$ 2017. Retrived from http://www.coe.int/sq/web/tirana/-/presentation-of-the-findings-fromthe-first-national-survey-on-bullying-and-extremism-in-the-education-system-in-albania

${ }^{2}$ World Report from Violence and Health, (n.d.). Chapter 2, Ëouth Violence. Retrieved from
} 
According to the Council of Europe (2017) study, school is an environment where bullies feel safe to exert violence against victims. To combat this phenomenon, the school should play its role properly. It should be the institution where the education process takes place in an organized manner, and not the place that favors the exercise of violence.

Almost every day, many media report violence exercised by teenagers in schools or on the street. Media analysts claim that violence is everywhere, the victims and the main authors of which are teenagers themselves. Violence by teenagers harms not only its victims, but also families, friends and the community they live in. The range of violence negative consequences is so wide that has led to an increase in the state's financial costs for the services provided. The presence of psychologists in schools, the presence of social workers, teacher training on conflict management in the classroom, seem to be state-of-the-art measures undertaken by the state. However, conflict still exists and sometimes it appears in some of the scariest forms: students, who mock, offend, beat each other with fists and chairs, exercise economic violence, cybernetics, bullying, class confusion, etc. (Kadiu, 2000). This shows that the matter of the impact of educational institutions on minimizing cases of violence requires a particular attention. Therefore, what this society needs is to identify the problem by determining its frequency, assessing tolerance against conflict between teenagers in schools, determining the level of attitudes among different actors in the school, and identifying strategies for minimizing conflicts.

The importance of this study consists in defining the level of involvement of teenagers in the conflict and the effectiveness of the services provided in schools to manage these conflicts. The objectives of this research are:

- $\quad$ Assessing the extent to which teenagers are involved in violent behavior within school environments.

- Determining the genesis of violent behavior by relying on Psychological Directions.

- Identifying the institution or the individual to whom the victims of violence report the violent case.

- $\quad$ Assessing the efficiency of school services in minimizing conflicts.

- $\quad$ Recommendations and suggestions for improvement.

Based on the Positivists Paradigm, we have to measure and recognize the reality so that we can see whether these conflicts between teenagers are not well managed by the school. In order to recognize reality, studies need to be made and key interventions for minimizing conflicts need to be defined in three levels: in family, school and community where we grow and develop each day.

\section{Literature Review}

\subsection{Violence among Young People Seen In the Perspective of Psychological Directions}

According to the study conducted by the Council of Europe (2017), the most vulnerable group exposed to violence is the one of high schools' teenagers. From the study it turns out that violence can be developed in various forms, such as physical, psychological, sexual, verbal, and so on. For a long time, scholars have tried to explain why it is happening. Although measures have been taken to limit it, violence is still present (Council of Europe, 2017).

Explanation of violent behaviors can be made under several perspectives. If referred to Psychoanalytic Direction (Freud, 2005), we can say that young people who exert violence are exactly those who once in childhood were themselves victims of violence. These children may have been subject of violence of their parents or their babysitters. Freud believed that the past experience, of which the person is unaware of, influences much on current behavior (Pettijohn, 1996, p. 14).

Humanistic Direction claims that none of the people is violent. This direction emphasizes the fact that people are complex organisms and that each individual possesses a capacity that allows him to reach maximum potential (Dibra, Zhilla, Muçaj \& Xhakollari, 2010, p.11).

Violent behaviors can be also studied under Behavioral Direction. According to this direction, the society, the environment that surrounds us, pushes us to display such behaviors. Skiner thinks that external forces are those that act on the individual and that do not treat him as free to make decisions (Pettijohn, 1996, p.407).

http://www.who.int/violence_injury_prevention/violence/global_campaign/en/chap2.pdf 
In each of these directions we can see some form of explanation of violent behaviors.

\subsection{Mindsets in Violence Explanation}

Alongside the psychological explanations, there are Albanian mentalities that justify violent behavior through expressions like "Who beats you, loves you", thus disrupting the climate of understanding (Kadiu, 2000, p. 83). But it is not just that. There are several instances during which state institutions remained indifferent to such intolerable behavior. Albanian parents often justify the violent behavior of their children by mentalities such as kids are young, and aggressive behavior decreases with growing age (Jorgaqi, 2001). Apparently, we see a negative correlation between teen age and aggressive behavior. The more the age increases, the fewer models of violent behavior we have. In fact, from the findings of the Council of Europe \& ISOP study on bullying and violent extremism in Albanian schools, it turns out that with increasing age the level of violent behavior increases. Class $11^{\text {th }}$ was the one that resulted in a higher number of students displaying violent behavior and one of the most common forms was verbal violence (ISOP, 2017, p.22). Students admit that they themselves or their friends in the 9-year school were wiser and quieter, and in high school they appeared to be more aggressive and violent. According to a study conducted in some countries around the violent behavior of young people, it turns out that the age-group that is most violent is the one of 16-17 years. Exactly these years of life where more violence is exercised, are termed "the path of continuous development of life" 1 (World Report of Violence and Health, n.d. p.30).

\subsection{Factors Affecting Violent Behaviors}

Family environment and school are external factors that influence conflict management. Parents, who show little control over their children, but also those who use fierce physical or emotional punishments, model and cultivate violent behavior on today's youth. It was once believed that increasing punishment intensity increases its effectiveness, but it's not like that. If the punishment is taken into consideration, its most softened forms should be used (Musai 1999, p.104). Studies so far show that during adolescence the impact of the family decreases and it is strengthened more and more the influence of peers. Teenagers are locked into their social shell by shrinking the influence from family members. The family, which during the childhood period orientated the child to the right choices, is in weaker position during adolescence (Çelçima, 2017). Referring to studies about adolescence, the latest is perceived as a period of biological, psychological and socialeconomic transformation. During middle-aged adolescence, the individual is characterized from uncontrollable emotional outbursts, interest in reproduction, from sensation that they are now adults, smarter, and can make decision themselves (Çelçima, 2017, p.99). It is at this stage of life that the role of the school, the school's teacher or the school's psychologist should be strengthened. Too difficult, but necessary to have a civilized and less violent society (Stigler \& Hiebert, 1999). Also, according to Sigmund Freud, it is shown that wrong actions have a hidden motivation, and therefore psychoanalysis is used to pave the way for the recognition of this motivation (Dibra, Hida, \& Gjikondi, n.d., p.271).

\subsection{The School and the Conflict}

The school is the institution where the education process takes place in an organized manner (Pino, Brahja, \& Gjipali, 2016, p.42). And yet, this does not mean that the school should only learn writing and reading. It should increasingly pay attention to its secret functions as the socializing function, promoting creativity, emotional support, and so on. In schools we have teenagers who come from different provinces and cultures. This has made it difficult to establish lasting relationships between teenagers (Tamo, 2012). Failure to respect cultural values turns out to be a catalyst for the emergence of conflicts. What we need to understand is that the cultural groups are heterogeneous inside them and embrace a range of practices and various norms, which are often debated, changed over time, and applied by individuals in personalized ways (Barrett, 2016, p.19-21). Researcher Shapiro says that if we start from a prejudicious point of view from the beginning, our understanding and communication with them would be less fruitful. Consequently, our communication fails. In this way conflict becomes more and more destructive (Shapiro, 1997, p.90). Also, other studies show that conflicts in the classroom spoil the atmosphere of understanding and work not only within the class but also at school (Kadiu, 200, p.77). Many teenagers do not understand what is happening around them, so it is necessary to have a psychologist in the school who translates the situation into a simpler and comprehensible language for the teenager. According to researcher A. Kadiu,

\footnotetext{
${ }^{1}$ Retrived from, Information Technology and Statistics Sector, 2017, DARQ. Tirana and elaborated from the author.
} 
adolescence is a stage of development where the individual is in crisis with himself, and inevitably even with others (Kadiu, A., 2000, p.12). In such a situation adolescents should increasingly be tolerant in their relationships.

Researches have shown that economic inequality of teenagers has consistently fueled violence among them. Just for a bit of money, teenagers violate each other and try to extort those who are weaker, less self-confident and isolated from other social groups. The latest fall prey to bullying or violent extremism. Faced with all these difficulties, the school is the one who follows different strategies to manage the conflict and foster the spirit of co-operation and tolerance among teenagers. The frequent provision of social services and psychologists is one of the ways to hold back violent behaviors that are evidenced mostly by teachers (Council of Europe \& ISOP, 2017, p.32).

\section{Research Methodology}

\subsection{Research Method and Research Design}

The data of this article is derived from the study conducted in two high schools, "Krrabë" and "lbrahim Hasmema". These two schools are located between Tirana (the capital of Albania) and Elbasan, which is a well developed city. Schools are located in a rural area and for the academic year 2016-2017 they have had a total of 403 students ${ }^{1}$. The population of this study is composed by 1,267 high school students located in the villages between Tirana and Elbasan. The randomly selected sample consisted of 370 students from "Krrabë" and "Ibrahim Hasmema" schools. The research method used is the quantitative one and the tool used to collect the data is the questionnaire. Sample selection criteria are:

- Students of the 10th, 11th and 12th grades

- Girls and boys

Questionnaires were completed by 370 students in grades 10,11 and 12 . In the survey participated all students who were in the school premises on the day the questionnaires were completed. Time to complete the questionnaire was $45-50$ minutes.

Table 1: Number of students enrolled in schools located in the area between Tirana and Elbasan for the academic year 2016-2017

\begin{tabular}{|c|c|c|c|c|c|c|}
\hline School & $\begin{array}{l}\text { Total Number of } \\
\text { Students }\end{array}$ & Females & Males & $\begin{array}{l}\text { Numb } \\
\text { Total }\end{array}$ & ndents & Male \\
\hline Baldushk & 180 & 71 & 109 & & & \\
\hline Mersin Duqi & 75 & 51 & 24 & & & \\
\hline Kllojkë & 81 & 38 & 43 & & & \\
\hline Fark & 259 & 136 & 123 & & & \\
\hline Krrabë & 107 & 55 & 52 & 89 & 49 & 40 \\
\hline Sadi Nuri & 269 & 135 & 134 & & & \\
\hline Ibrahim Hasmema & 296 & 140 & 156 & 281 & 130 & 151 \\
\hline
\end{tabular}

These data served to collect information about what teenagers perceives with term violence. Have they ever been victims of violence and whether they have denounced it somewhere? Are they affected by their friends to display violent behavior? Do they use social services provided in schools? Which of the sexes is more a victim of violence? The survey was also used to get information on the attitudes these young people have when they feel violated. Quantitative research method

1 This article was produced from the unpublished master thesis called 'The Cuisine in Muhammad's Era' (Sakarya University, Institute Social Sciences, Sakarya 2007) written by Sevim Demir Akgün and supervised by Prof. Dr. Levent Öztürk. 
was chosen because the anonymity of questionnaires allows teenagers to be freer in giving feedback without fearing to be prejudiced. In addition, questionnaires are easily completed by a large number of people within a short time (Bailey, 1982).

The elaboration of statistical data using the Statistical Science Package for Social Science (SPSS) will help explain the research objectives:

$$
\begin{aligned}
& \text { Assessing the extent to which teenagers are involved in violent behavior within school environments. } \\
& \text { Determining the genesis of violent behavior by relying on Psychological Directions. } \\
& \text { Identifying the institution or the individual to whom the victims of violence report the violent case. } \\
& \text { Assessing the efficiency of school services in minimizing conflicts. } \\
& \text { Recommendations and suggestions for improvement. }
\end{aligned}
$$

This research will serve as a way of assessing the needs of teenagers in order for them not to be involved in conflictgenerating violence. Also, appropriate recommendations will be provided to strengthen the school's role in conflict management among teenagers.

\subsection{Reliability and Validity of the Instruments}

To test the reliability and validity of the questionnaire, the latest was first applied to two pilot classes of the Sander Prosi high school, located in one of the rural areas of Tirana. To complete the questionnaire, 60 students were randomly selected. Taking into account the faced difficulties, reactions, responses and recommendations on the questionnaire's items, the latest was further elaborated and improved. Using a simpler language, avoided the prejudices and made the survey more understandable by the students who are the sample of this research. The result of the pilot study show that the reliability score for all items is Cronbach alpha $(a)=0.891$. This value indicates that the questions are sufficiently related and have a high level of trustworthiness. The validity of the questionnaire content was determined by experts from the Faculty of Social Sciences in Tirana and by experts from the Faculty of Economics in Elbasan. Their consultation aimed to avoid unclear and prejudicial words, providing ease of understanding in terms of questions, as well as inputting data for its statistical processing.

\section{Data Analyses and Discussions}

The "Krrabë" and "Ibrahim Hasmema" schools which make up the sample of this research have a homogeneous population. Students belong to the same age group, are residents of the same village and have a common culture. The results of the descriptive analyzes of this study revealed that the conflict was present here as well. $94 \%$ of students claimed to have displayed violent behavior at school premises and only $3 \%$ of them claimed they did not exhibit violent behavior. This is a high percentage of students who think they have shown violent behavior in school environments. This situation requires immediate intervention in school management policies.

Graph 1: Have you ever shown violent behavior in school premises?

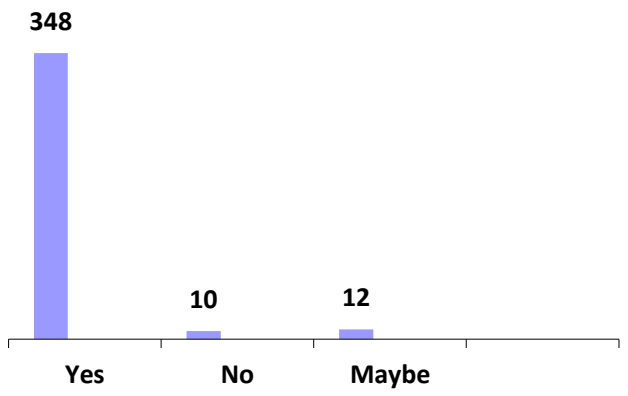


When students were asked if their parents used violence against them during childhood, $81 \%$ of respondents or 300 students said that their parents did not violate them at all, $8 \%$ or 31 students said that their parents violated them a little, $7 \%$ or 27 students said they were somewhat violated, and only $3 \%$ or 12 students expressed that they were heavily abused from their parents. From the data it results that we do not have a Psychoanalytic Direction approach to explain violent behavior because most of these students, 300 students, have reported as not having previously been violated by their parents.

Also, in order to recognize and describe the source of violent behavior, students were asked to choose between Psychological Directions, the one they find as a more appropriate approach. When students were asked to choose to which of the statements they agree the most, the results of the questionnaire indicates that we have a more approximate approach with the Behaviorist Direction.

- $\quad$ Psychoanalytic Direction - Teenagers who exercise violence are precisely those who, during childhood, have been victims of violence.

- $\quad$ Humanist Direction - People are complex organisms and possess the capacity to achieve maximum potential.

- $\quad$ Behaviorist Direction - External forces are those that act upon the individual and do not leave him free to make decisions.

Students think that for decision-making they are driven by external forces that may be parents, school's teachers, society, etc. For this finding, another more specific study is needed in the direction of closest relationship between teenagers.

Based on the questionnaire's data, only 198 students, or $54 \%$ of the sample selected for this study, were previously victims of violence at school premises, of which $68 \%$ were males and $32 \%$ were females. Apparently their physical strength can not help them not to be victims of violence.

Table 2. Number of students who claim to have been victims of violence in school environments.

\begin{tabular}{|c|c|c|c|c|}
\hline Total students & \multicolumn{2}{|c|}{ Violence Victims } & \multicolumn{2}{|l|}{ in $\%$} \\
\hline \multirow{3}{*}{370} & \multicolumn{2}{|l|}{198} & \multicolumn{2}{|l|}{$54 \%$} \\
\hline & Females & Males & Females & Males \\
\hline & 64 & 134 & $32 \%$ & $68 \%$ \\
\hline
\end{tabular}

Another question from the questionnaire was on where the students report if they are victims of violence. This question serves to test how effective the services provided by the school are in managing conflicts within it.

Graph 2: Where do you report if you are a victim of violence?

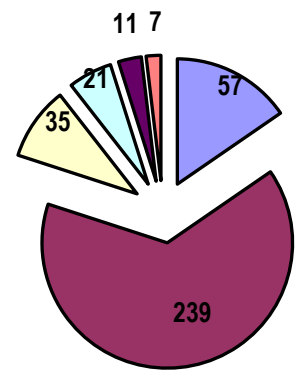

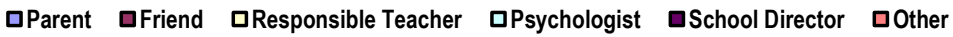

From the data processing it results that only 67 of the students report violence to the school psychologist, the teacher or the school principal. This is only $33 \%$ of the students who claim to have been victims of violence. The data show that we have a low credibility of students to the school institution and the services it provides. 
To understand the school's response to the cases of reported conflicts, the students were asked what happened after they reported the conflict. Questionnaire data show that the percentage of cases when the school has taken measures to end the conflict was considerable, but in $40 \%$ of cases the conflict has continued again.

Graph 3: What happened after you reported the conflict?
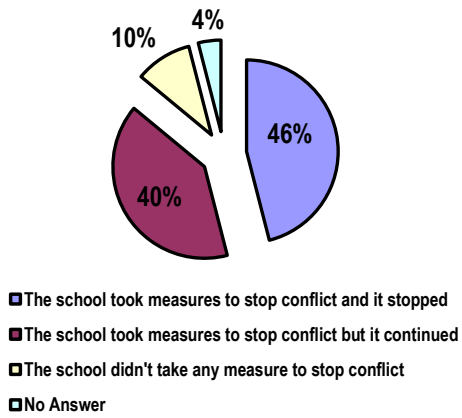

To explore the potential for future research, students were asked to express their belief whether the school plays an important role in conflict management among teenagers. Although $40 \%$ of students reported that the intervention of school services could not stop the conflict, $87 \%$ of students believe that the school can play a very crucial role in conflict management. There are many potential spaces that can be used to have a spirit of collaboration between school and students.

\section{Conclusions and Recommendations}

In Article 36 of the Normative Provisions for Pre-University Education, "Rights", is quoted: "The individuality and human dignity of the pre-school child and the student is respected, he is protected from physical and psychological violence, discrimination and isolation. In the kindergarten and in the school it is prohibited the physical punishment or the humiliating and denigrating treatment of the child (Normative Provisions, 1998, Art. 36). Although the law for the protection of juveniles against forms of violence exists, again we see violence being exercised against them.

Individuals go through different stages of development, so strategies for preventing violent behavior should start in childhood. According to Psychoanalytic Direction, the teenager's past is important to explain his behavior in the future. The more violated the teenager has been during his childhood, the more likely it is for him to display violent behavior during the adolescence period. By getting a better education in the family, the school will have it easier to manage the situations of violence. One of the main measures suggested is the immediate training of parents on the methods they can use to educate their children. The appearance of violent behavior has consequences not only for the victim, but also for the relatives of the parties involved in the conflict. Therefore, the first and immediate intervention must be in the family.

Given the degree of homogeneity in rural areas, it was thought that young people were more familiar with each other and conflicts would be less present. In fact, from analyzing data in this study, it turns out that violence exists and in some cases we do very little to limit it. This violence does not come as a result of a violent past that teenagers might have had, but comes as a result of the impact that external forces have on the individual. It is therefore suggested that some of the interventions have to be on the social actors surrounding teenagers. Today's teenagers need positive models and we as parents or teachers should be willing to provide this service. Interventions should aim at strengthening the family-schoolcommunity partnership, prompting more and more parental participation in open-air activities or hours organized by the school.

198 students from respondents in this study were victims of violence. What is noticeable is that only 67 of them report the cases to the services offered at school. This shows that more needs to be done to strengthen the relationship between school and students. The school is one of the places in which violence might be favored. It is important to take measures to prevent the conflict between teenagers in these environments. The school should aim at promoting tolerance and 
promoting positive behaviors to students. It should inspire new talents and organize practical activities aimed at student participation for their entertainment and socialization. Encouraging extracurricular activities and creative work in the group will help even more the teenagers to stay away from violence. School programs increasingly need to be focused on teenager's anger management, building social skills, and conflict resolution.

Psycho-social service needs to be closer and closer to teenagers. School psychologists should be constantly looking for students who need more counseling. They should not stay expecting the next student who does not want to attend the lesson and turns to the psychologist's office to advise. The presence of the school psychologist in Albania is only twice a week. Survey data shows that compared with the problems, their presence is rare. This also affects the decrease of the trust that these teenagers have toward this service.

Some of the students who report to the psychologist, the teacher or the school's principal, find no solution to their problem because the conflicts persist again. It is not enough to have only the teacher presence around in the school premises. It is important as well to have the emotional and psychological support of social workers. When there is conflict or exercise of violence, it is the psychologist who interferes with his professionalism (Tamo, 2012, p.86-89).

In some professions such as the teacher, there should be engaged professionals who not only transmit knowledge but also provide emotional support for teenagers. Through this study, it is suggested to train schools' staff (teachers, directors and psychologists) so that they are 'skilled' in identifying students who tend to show violent behavior and in building strategies to limit conflicts that may generate violence.

However, a profession is not created by certifications but by the existence of sufficient professional knowledge, the existence of a mechanism to improve it and the true desire of members of this profession to improve their practice (Stigler \& Hiebert, 1999). Teachers should not only be trained for specific topics, but at the same time associate their work with the desire to be more effective in their noble mission of generations' education. Only in this way we can stop the violent actions among young people aiming to offer a more tolerant and social community.

The questionnaire also shows that boys are more involved in conflicts; in their ranks we find the highest number of victims. Therefore, it is suggested that the target group with which more work should be done and which should be the focus of interventions for conflicts minimization in school environments, should be boys.

Finally, our respondents tend to positively perceive the role that schools have in conflict management. Although teenagers think the school has not stopped the conflict, they are characterized by a high level of trust that the school and the services it provides, can manage it.

\section{References}

[1] Bailey, K. D. (2nd Ed.). 1982, Methods of social research. London: Collier Macimillian Publishers.

[2] Barrett, Martyn. 2016. Kompetencat për kulturën demokratike: Të jetosh së bashku si i barabartë në shoqëri demokratike me larmi kulturore. Council of Europe Publishing, Strasbourg. Pp. 19-21.

[3] Çelçima, Denis. 2017. Adolescents and the challenges in their motivation. European Journal of Social Sciences Education and Research. Vol.9. Nr. 2. Pp. 99.

[4] Dibra, G., Zhilla, E., Muçaj, A., \& Xhakolli, L. 2010. Psikologji 11, Shtëpia Botuese "ERIK”, Tiranë, Pp.11.

[5] Dispozita Normative (Për arsimin parauniversitar), Kreu VIII, (Për disa shtesa dhe ndryshime në ligjin nr. 7952, datë 30.07.1998, http://www.arsimi.al/dispozitat- normative

[6] Freud, Sigmund: Psikopatologjia e jetës së përditshme, Shtëpia Botuese "Fan Noli", Tiranë, Përktheu nga origjinali: 1940, Zur Psychopathologie des Altagslebens, Edit Dibra, Rexhep Hidra, Tamara Gjikondi, Shtëpia Botuese Fan Noli, Pp. 271.

[7] Freud, Sigmund. 2005. Psikoanaliza fëminore, përkthyer nga origjinali me titull Zëei Kinderneurosen, Kledia Baci, Shtëpia Botuese Fan Noli.

[8] Jorgaqi, Arian. 2001. Dhuna në shkollë: Dhe çështje të zgjidhjes së saj, Shtëpia Botuese APOLLONIA. Pp. 7-9.

[9] Kadiu, Arian. 2000. Adoleshentët dhe tranzicioni, Shtëpia Botuese "Fllad". Pp. 12-17.

[10] Musai, Bardhyl. 1999. Psikologji edukimi, Shtëpia Botuese PEGI. Pp. 104-111.

[11] Pettijohn, F. Terry. 1996. Psikologjia: Një hyrje konçize, Shtëpia Botuese "LILO", Tiranë. Pp. 404-407.

[12] Pino, S., Brahja, E., and Gjipali, S. 2016. Qytetari 10, Shtëpia Botuese Albas. Pp. 42. 
[13] Presentation on the findings from the national survey on bullying and violent extremism in the education system in Albania. 2017. Founded by the European Union and Implemented by the Council of Europe, pp.19. Retrieved from https://rm.coe.int/168070c3be

[14] Republika e Shqipërisë Ministria e Arsimit dhe Shkencës. 2013. Dispozitat Normative për Sistemin Arsimor Parauniversitar. Retrived from http://www.arsimi.gov.al/files/userfiles/parauniversitar/dispozitat-normative.pdf

[15] Stigler, J., \& Hiebert, J. 1999. The teaching gap, Neë York: The Free Press. 3

[16] Solnit, J. Albert, 2002. The Psychoanalytic study of the child, Vol. 56, New Haven; London: Yale University Press.

[17] Save the Children. 2007. Dhuna ndaj fëmijeve në shkolla. Retrieved from https://albania.savethechildren.net/sites/albania.savethechildren.net/files/library/Violence\%20Against\%20Child ren $\% 20$ in $\% 20$ Schools.pdf

[18] Shapiro, Daniel. 1997. Konflikti dhe komunikimi, Botim I Fondacionit "SOROS" për Shqipërinë. Tiranë. Pp.90.

[19] Tamo, Adem. 2012. Nga kriza shkollore te trauma psikologjike, Shtypshkronja "albPAPER". Pp.86-91.

[20] United States Department of Health and Human Service. 2001. Youth violence: a report of the Surgeon General, Washington, DC.

[21] Zyra e Këshillit të Evropës në Tiranë, ISOP, 21 Prill 2017. Retrieved from http://www.coe.int/sq/web/tirana//presentation-of-the-findings-from-the-firstnational-survey-on-bullying-and-extremism-in-the-educationsystem-in-albania, pp.19-22.

[22] World Report from Violence and Health, (n.d.). Chapter 2, Youth Violence. Retrieved from http://www.who.int/violence_injury_prevention/violence/global_campaign/en/chap2.pdf 